\title{
City not to blame for poor science investment by British industry
}

\section{London}

THE failure of British industry to improve on its poor record of investment in research and development cannot be blamed on shareholders anxious to see high short-term profits at the expense of long-term stability, according to a survey published last week. It is often the companies themselves that neglect to give sufficient weight to long-term development, mainly because of underlying economic and political factors, including inadequate profitability.

The popular argument is that stock markets lay too much weight on current profits and current dividends. Companies respond to this pressure by pursuing shortterm profit goals a the expense of longerterm investment.

After a year-long study, a 29-man task

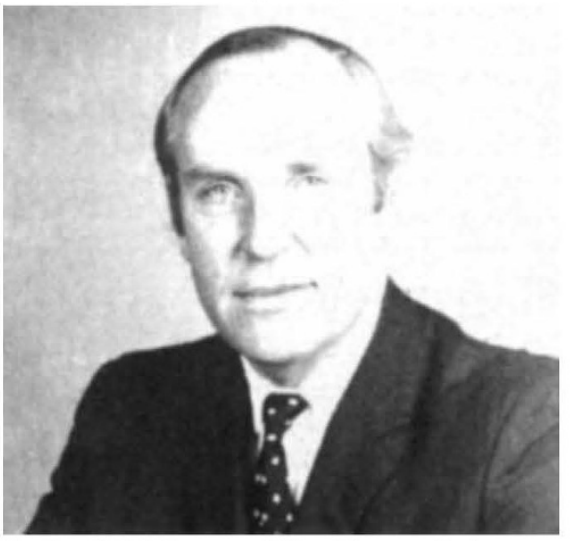

Sir David Nickson - debunking mythology.

force of the Confederation of British Industry $(\mathrm{CBI})$, chaired by $\mathrm{CBI}$ president Sir David Nickson, found that many of the commonly held perceptions surrounding the relationship between industry and the City were "simply not supported by the available facts". They were part of a "pervasive mythology that needs to be debunked in the interests of both the City and industry alike". The task force found that most financial institutions (such as pension funds) are long-term investors "not surprisingly in view of the long-term nature of their obligations".

At the heart of the problem, according to the task force, lies a communications gap between management, owners of companies and those providing finance. British industry invests less than one per cent of the nation's gross domestic product in research and development, less than its major competitors. But no evidence exists to attribute this to 'shorttermism', the report says. Indeed, industries where long-term investment is crucial, such as oil and pharmaceuticals, enjoy high price earning ratings, reflecting the long-term growth prospects expected

\section{from current investment.}

A poll among company chief executives showed that financial market activities were not the most important constraining influence on companies' investment plans. Most felt constrained by either the cost of capital or fear of an inadequate return on their investment.

Another common perception is that the City is not prepared to raise funds for small businesses or high-risk ventures. Not so, say Nickson and his team. Some $£ 396$ million of equity and loans were provided by venture capital companies to UK companies in 1986, in amounts of between $£ 100,000$ and $£ 1$ million, compared with $£ 279$ million in the previous year and $£ 110$ million in 1982 . All the main banks and financial institutions have their own venture capital funds.

What the system needs, the report concludes, is improved communications.
Companies must make more effort to keep the market informed. Shareholders and analysts must be given more information about companies' innovation activities. The government has indicated that it would like to see companies routinely reporting research and development expenditure in their annual accounts. Although the government says it would prefer a voluntary system, it does not exclude the possibility of legislation.

The CBI task force is opposed to statutory disclosure, and notes that for singleproduct companies and those that do not carry out research and development regularly, disclosure could mean revealing commercially sensitive information. The task force would support the introduction of a statement of standard accounting practice which leaves open the possibility of not disclosing if there is a sound reason. The disclosed figure of research and development spending should be put in its proper context by explaining how the research and development fits in with a company's overall strategy.

Simon Hadlington

\section{California gives radiation-safety violations a short half-life}

\section{San Francisco}

CALIFORNIA researchers are suddenly acutely aware that they are personally liable to prosecution for radiation violations by members of their laboratories. This lesson has sunk in after criminal charges were brought against 10 members of the University of Southern California (USC) for violations of the radiation regulations. Although the charges against individual investigators have been dropped, the effects of the case continue to reverberate through the scientific community.

The USC case began in 1986, when a routine state radiation inspection found violations in several biomedical laboratories. Most were minor and, according to the university, posed no health threat. But the state turned its investigation over to the Los Angeles city attorney, who last March filed 179 criminal misdemeanour charges against the university and individual investigators. One investigator was charged on 21 counts, each carrying a maximum penalty of a $\$ 1,000$ fine and/or six months in gaol.

Steve Auer, attorney for USC, said he was surprised that the city attorney had filed criminal charges against the individuals. He had expected civil charges, which carry lesser penalties and less stigma, to be filed against the university. University of California (UC) attorney, John Lundberg, agreed, adding that to charge individual investigators is "grossly unfair". Lundberg said there was never any talk of charges against individuals when state inspectors found 33 radiation violations at UC San Francisco last March. Civil charges against UC have been threatened but not filed in that case, he said.

But the Los Angeles district attorney's office stands by its action. "The university as a corporation is a fictional entity", said spokesman Steve Tekosky, "and it can only violate the laws as individuals violate the laws." Tekosky said he knew of no other case in which individual university faculty members have been held responsible for radiation violations.

On 1 October, all but 15 of the charges were dropped, including all of those against individuals. USC pleaded no contest to the remaining charges and paid a $\$ 25,000$ fine. But the state's initial harsh action achieved its goal: USC overhauled its radiation safety programme and has satisfied the city attorney's office that it is now in total compliance with regulations.

Researchers around the state are expressing alarm at the criminal indictments at USC by signing a petition denouncing the use of such "exaggerated measures". Copies have begun to arrive at the office of the state legislature's committee on science and technology.

The petition supports the need for effective enforcement of safety regulations, but criticizes criminal indictments as "regulatory over-reaction". It also notes that such draconian measures may force researchers to consider positions in "more enlightened" states. Marcia Barinaga 